\title{
Effects of Shariah Supervisory Board Characteristics on Credit Risk of Islamic Banks
}

\author{
Siti Solehah Ghazali, Rohaida Basiruddin, Nor-Aiza Mohd-Zamil
}

To Link this Article: http://dx.doi.org/10.6007/IJARAFMS/v11-i4/11116 DOI:10.6007/IJARAFMS /v11-i4/11116

Received: 19 October 2021, Revised: 20 November 2021, Accepted: 29 November 2021

Published Online: 14 December 2021

In-Text Citation: (Ghazali et al., 2021)

To Cite this Article: Ghazali, S. S., Basiruddin, R., \& Mohd-Zamil, N.-A. (2021). Effects of Shariah Supervisory Board Characteristics on Credit Risk of Islamic Banks. International Journal of Academic Research in Accounting Finance and Management Sciences, 11(4), 29-43.

\section{Copyright: @ 2021 The Author(s)}

Published by Human Resource Management Academic Research Society (www.hrmars.com)

This article is published under the Creative Commons Attribution (CC BY 4.0) license. Anyone may reproduce, distribute, translate and create derivative works of this article (for both commercial and non-commercial purposes), subject to full attribution to the original publication and authors. The full terms of this license may be seen at: http://creativecommons.org/licences/by/4.0/legalcode

Vol. 11, No. 4, 2021, Pg. 29 - 43

Full Terms \& Conditions of access and use can be found at http://hrmars.com/index.php/pages/detail/publication-ethics 


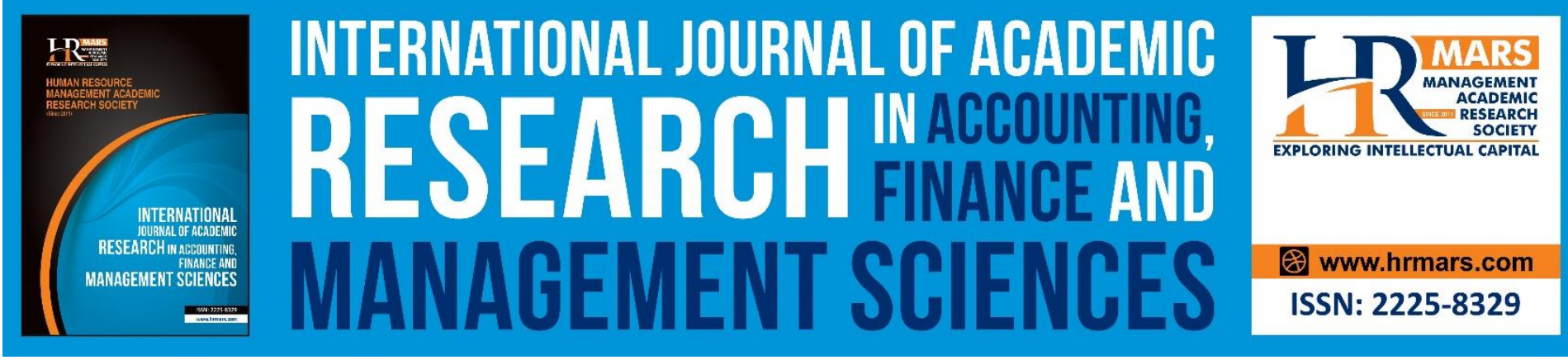

\title{
Effects of Shariah Supervisory Board Characteristics on Credit Risk of Islamic Banks
}

\author{
Siti Solehah Ghazali ${ }^{1,2}$, Rohaida Basiruddin ${ }^{1}$, Nor-Aiza Mohd- \\ Zamil $^{1}$ \\ ${ }^{1}$ Azman Hashim International Business school, Universiti Teknologi Malaysia, Kuala Lumpur \\ ${ }^{2}$ School of Economics, Finance and Banking, Universiti Utara Malaysia, Kedah \\ Email: ssolehah@uum.edu.my (Corresponding author)
}

\begin{abstract}
The purpose of this paper is to examine the relationship between the effective characteristics (i.e. size, independence, female board, meeting frequency and remuneration) of Shariah supervisory Board (SSB) and its effects on the credit risk of Islamic banks (IBs). The study based on 504 Islamic bank-year observations from 56 banks in 18 countries between 2009 and 2017. The findings suggest that the SSB in Islamic banks with smaller size, the lower composition of female directors and higher remunerations are more likely to have lower credit risk. However, no evidence suggests that SSB with more independent directors and higher meeting frequency reduce the credit risk in Islamic banks. These findings will be of potential interest to policymakers and professionals in strengthening the role of SSB in Islamic banks. Moreover, the countries represented in this study have made significant contributions to the infrastructures of Islamic financial institutions around the world. Finally, the study outcome might also serve as another model for countries which seek to strengthen the role of SSB in managing IBs credit risk.
\end{abstract}

Keywords: Shariah Supervisory Board, Credit Risk, Size, Independent, Female, Remuneration, Islamic Banks

\section{Introduction}

In Islamic banks (IBs), credit risk is considered as an important financial risk compared to other risks (Khan \& Ahmed, 2001). They also found that credit risk in IBs represents more than 75 percent on average of banking book asset portfolio and bank failures. Specifically, this is because the practice mode of financing in Islamic banking is based on PLS(Profit-loss-sharing). It was then Supported by El-Hawary et al (2007) that moral hazard incentive to lenders in the PLS contract could lead to high credit risk in IBs. According to Ahmed and Chapra (2002), IBs incorporate a diversity of Islamic contracts into their product in order to evade Riba, Gharar, and Maysir. Thus, credit risk is included in actions exposed to a variety of risks in IBs. In IBs, the financing relationship is recognized based on partnership. Therefore, IBs are unable to mitigate credit risk or business failure, and the also lack of strong control over the management of the projects they finance (Usmani, 2008). For example, the risk connected to the business venture or the project is shared by the IBs and the financing client under the 
Musharakah financing arrangement. The Mudarabah financing principle is at a higher risk. Both the IBs and borrower share profits gained from the project according to the ratio of predetermined profit-sharing. Nonetheless, if there is a loss, the borrower incurs a loss of time and effort invested on the project or business venture management; meanwhile, the IBs bears the entire cost. Ramly and Nordin (2018) stated that the primary basis for the PLS financing arrangement is trust. It can be done by conducting meticulous credit evaluations and business viability, IBs can reduce the risk of losing their capital contribution to the project. Hence, the IBs should appoint independent members of the boards who are not beholden to management, such as the Shariah Supervisory Board (SSB), to achieve this objective. Precisely, Hasan (2009) stated that the main purpose of SSB is to apprise the boards of directors on Shariah related matters. Meanwhile, AlAbbad et al (2019) demonstrated that SSB works as an autonomous control mechanism that works with the board of directors to ensure and certify that all relevant products and activities, including service records, internal policies, manuals and marketing advertisements, adhere to Shariah law. Therefore, Mollah and Zaman (2015) argued that the additional function of the board of directors can be completed by adding SSB as the layer of corporate governance.

Unnecessary and excessive risk-taking are prohibited in Islam. Thus, SSB is critical in ensuring that financing contracts adhere to Shariah law and advising the board of directors on contract risk (Abedifar et al., 2013; Mollah et al., 2017). In light of the vital role of SSB in IBs, the past research mostly focused on studying the shariah governance framework (Alam et al., 2021; Chowdhury \& Shaker, 2015), the SSB challenges (Abozaid, 2016) and the role of the effectiveness of SSB (Ulfi et al.,2020). However, little is known on how SSB characteristics attribute to the bank outcome. Mollah et al (2017) previously discovered that SSB has been shown to reduce risk-taking, as religiosity restrains risk-taking when integrated with a strong board (small board size and higher independent members). However, Mollah et al (2017), on the other hand, did not delve into specific Shariah Supervisory Board (SSB) characteristics found in Islamic bank governance. As a result, this study includes specific variables relating to SSB characteristics to examine the relationship between credit risk in IBs. Therefore, this study contributes to a discussion on the implications of IBs development. Specifically, we extend previous work on IBS and credit risk by examining specific SSB characteristics by considering the fact that it affected credit risk. Additionally, this study serves as a valuable resource for boards of directors as they establish corporate governance structures within IBs. In addition, a key role of SSBs is to ensure financial products and services offered in IBs comply with the Shariah law. As Islam Prohobitted financial transaction that are exposed with high risk, high uncertainty and inappropriate moral hazard (Gharar) (Hamza \& Saadaoui, 2013). Therefore, managing risk, especially credit risk, is highly important. This study contributes to the literature, particularly in the field of shariah governance which allows SSB characteristics to have an impact on managing IBs credit risk. The rest of this paper is organized as follows: Section 2 discusses the literature review and hypotheses development; Section 3 emphasises on data sources and sample selection. The empirical result and discussion are reported in section 4. Finally, section 5 concludes the research.

\section{Literature Review and Hypotheses Development}

The agency problem is an important issue that a firm needs to deal with. Thus, corporate governance was created in order to solve the issue. Traditionally, agency theory can be understood from early research by Jensen and Meckling (1976) that there is a conflict of 
interest between managers and firm owners. According to Leaven and Levine (2009), banks are more exposed to agency problems as compared to other financial institutions because they own a special characteristic. As argued by John and Qian (2003) the agency problem in banks happens due to the difference of interest between depositors and shareholders. Conventional corporate governance, on the other hand, differs in some ways from the concept of Islamic corporate governance. For instance, corporate governance's fundamental principles are held to benefit the company and its shareholders. Additionally, according to the Islamic concept, it is accountable to Allah (Abu-Tapanjeh, 2009). On top of that, there is one critical component of Islamic corporate governance which is unique: the Shariah Supervisory Board (SSB). Specifically, this study uses agency theory to examine the effect of SSB characteristics on credit risk. This study focuses on five characteristics of SSB, namely SSB size, SSB independent, SSB female, SSB meeting frequency and SSB remuneration. This study also controls the size of the IB and Listing on the bank level. Finally, we control GDP and inflation level of the country. The selection of SSB characteristics is based on the resources that have risk implications towards the decisions made by IBs. Therefore, an emphasis hypothesis is discussed below:

Board size is a significant characteristic that influences the board's effectiveness in supervising managers and reining their opportunistic behaviours (AlAbbad et al., 2019). In IBs, the authority of the decision making related to shariah compliance issues is made by SSB. Thus, the size of SSB may have an effect on the role and decision-making's effectiveness (Najwa et al., 2020). As argued by Chaganti et al (1985), firms which have larger board size lower risk of bankruptcy, and they enjoy lesser uncertainty (Birnbaum, 1984), and have less information asymmetry (Chen \& Jaggi, 2000). In addition, Yermack (1996) also stated in his studies on corporate governance where he found that a smaller corporate board size is more preferable among the firms because it allows for better communication and effectiveness. A smaller size board of directors positively affects firm's risk-taking decision because a smaller size of board is expected to efficiently administrate the bank's managers in the interest of shareholders who are incentivized to take more risks (Cheng, 2008; Pathan, 2009). In addition, Alman (2012) discovered that as the number of SSBs and Shariah scholars increases whilst having multiple memberships on the SSBs, this would positively affect loan portfolio risk. Furthermore, Bourakba and Zerargui (2015) examined 12 selected international banks in the Middle East and discovered that larger SSBs had lower credit risks. Based on the discussion above, the first hypothesis for this study was developed as below:

Hypothesis 1: There is a significant positive relationship between SSBs and credit risk.

The importance of independent members on boards of directors has been demonstrated in previous research. For example, prior studies by Fama and Jensen (1983) stated that the proportion of independent directors positively correlates with the managers' effectiveness in preparing financial reports. This is because independent directors possess more profound abilities, in-depth knowledge, and diverse experience and contribute value to the organization on improving its performance (Khan et al., 2020). The IFSB (2014) emphasizes the importance of independent directors in supervising risk-taking activities in investment banks. As Pathan (2009) argued, independent directors help protect the image and avoid losses of the firms by investing in low-risk projects. In the context of SSB, a high proportion of independent members can prevent the firm from taking an excessive risk during analysing investment proposal since the independent members can examine the investment proposal 
MANAGEMENT SCIENCES

Vol. 11 , No. 3, 2021, E-ISSN: 2225-8329 (C) 2021 HRMARS

in detail based on the check and balance without relying on the executive management team (Rachdi et al., 2013). For such reasons, SSB independent members would be effective in managing credit risk. For this reason, the second hypothesis is derived below:

Hypothesis 2: There is a significant positive relationship between SSBINP and credit risk.

According to psychological research and experimental economics, females are commonly risk-averse, as evidence by their investment decisions (Charness \& Gneezy, 2012). Similarly, empirical evidence from behaviour finance also supported that women have more risk aversion than men when making investment and financial decisions (Barber \& Odean, 2001; Halko et al., 2012; Faccio et al., 2016). This is because women are more sensitive towards different fairness principles when making decisions (Miller \& Ubeda, 2012). Croson and Gneezy (2009) summarised that the primary characteristics affecting gender differences in risk-taking are a different level of confidence, emotional reaction to risky situations, and uncertainty perception. Therefore, SSB can depend on women to identify the credit risk associated with financial contracts used to finance a product. Therefore, the third hypothesis would be as follows:

Hypothesis 3: There is a significantly positive relationship between SSBFP and credit risk.

The effectiveness and efficiency of a good decision of the firm are achieved by having board meetings regularly. According to Zabri et al (2016) board meetings help directors stay informed and updated on firm's development. Therefore, directors of a firm should attend board meetings to monitor, stipulate, supervise and make strategic decisions. Hence, attendance at board meetings fulfils a director's responsibility and should be associated with improved firm performance. Consequently, board meetings are critical in corporate governance, and abnormal number of board meetings have detrimental effect on the firm's value (Vafeas, 1999). Furthermore, since Islamic banks engage in various product transactions subjected to Shariah law obligations, the SSB members are compulsory to attend the meeting at least once a month as recommended by Muneeza and Hassan (2014). This is because frequent meetings held by the SSB will help IBs decide on credit risks, specifically regarding shariah compliant matters. Thus, the fourth hypothesis is proposed below:

H4: There is a significant positive relationship between SSBM and Credit Risk.

In corporate governance practices, Zalewska (2016); Becht et al (2011) stated that remuneration is significantly in line with contract and objectives of the shareholders. A study by Tung and Wang (2012) determined that high remuneration may reduce risk-taking of the bank. Unda and Ranasinghe (2019) stated that individuals exert more efforts when they received high remuneration. In perspective of IBs, SSB faces high level of difficulty in order to perform their duties in accordance to Shariah compliance. Hence, high remuneration should be paid to obtain an effective and diligent decision from SSB in reducing credit risk. Therefore, the fifth hypothesis of the study is derived below:

H5: There is a positive relationship between SSBREM and credit risk. 
MANAGEMENT SCIENCES

Vol. 11 , No. 3, 2021, E-ISSN: 2225-8329 (C 2021 HRMARS

The expected hypothesis for the control variable shows in table 1 below:

Table 1: The Expected Hypothesis for Control Variables

\begin{tabular}{|l|l|l|}
\hline Variable & Expected sign & References \\
\hline Bank size & - & $\begin{array}{l}\text { (Alzoubi \& Obeidat, 2020) (Waemustafa \& } \\
\text { Sukri, 2015) }\end{array}$ \\
\hline Listing & + & (Mollah et al., 2017) \\
\hline Real GDP & + & (Ramly \& Nordin,2018) (Ali et al.,2021) \\
\hline Inflation & + & $\begin{array}{l}\text { (Mollah \& Zaman, 2015)(Ahmad et } \\
\text { al.,2019) }\end{array}$ \\
\hline
\end{tabular}

\section{Sample Selection}

The current research focuses on IBs around the world. All information for all IBs was retrieved from Bankscope database. Over 150 IBs was found during the search procedure. As a result, there are 56 IBs in the final panel sample over nine years period between 2009 and 2017, with 504 IBs year observation from 18 countries: Bahrain, Bangladesh, Brunei, Egypt, Indonesia, Jordan, Kuwait, Lebanon, Malaysia, Palestine, Pakistan, Qatar, Saudi Arabia, South Africa, Thailand, Tunisia, United Arab Emirates and the United Kingdom. Table 2 reports the distribution of the sample by country.

The highest number of observations (72) in the United Arab Emirates represents about 14 percent of the sample, following Malaysia with (63) observations, representing about 15 percent of the total sample. On the other hand, Brunei, Lebanon, Palestine, South Africa, Thailand, and Tunisia have the lowest observation (9), representing 1.8 percent of the whole sample. Furthermore, information regarding SSB and bank-specific variables, namely listing, was manually collected from annual reports and specific bank websites. In addition, risk and bank size information was retrieved from bankscope. Finally, the country-specific variables, namely GDP and inflation, were collected from Thompson Reuters Datastream. 
Table 2: Samples Frequency of IBs Across Country

\begin{tabular}{lll} 
COUNTRY & FREQUENCY & PERCENT \\
\hline BAHRAIN & 36 & 7.14 \\
BANGLADESH & 45 & 8.93 \\
BRUNEI & 9 & 1.79 \\
EGYPT & 18 & 3.57 \\
INDONESIA & 36 & 7.14 \\
JORDAN & 18 & 3.57 \\
KUWAIT & 36 & 7.14 \\
LEBANON & 9 & 1.79 \\
MALAYSIA & 63 & 12.50 \\
PALESTINE & 9 & 1.79 \\
PAKISTAN & 45 & 8.93 \\
QATAR & 36 & 7.14 \\
SAUDI ARABIA & 27 & 5.36 \\
SOUTH AFRICA & 9 & 1.79 \\
THAILAND & 9 & 1.79 \\
TUNISIA & 9 & 1.79 \\
UNITED ARAB EMIRATES & 72 & 14.29 \\
UNITED KINGDOM & 18 & 3.57 \\
TOTAL & $\mathbf{5 0 4}$ & $\mathbf{1 0 0 . 0 0}$ \\
\hline
\end{tabular}

\section{Methodology of The Research}

This study examines the shariah supervisory board size and its characteristics and credit risk. To test the impact of the present SSB characteristics on the risk, we estimate the following regression model:

Model 1

Risk $_{i, t}=f \quad\left(\right.$ SSBS $_{i, t}$, SSBINP $_{i, t}$, SSBFP $_{i, t}$, SSBM $_{i, t} \quad$, SSBREM $_{i, t}$, control variables (1)

Where; Risk is measure based on the credit risk of the bank $i$ and year $t$, SSBS is shariah supervisory board size, SSBINP is Shariah Supervisory board independent, SSBFP is Shariah Supervisory board female, SSBM Shariah Supervisory Board meetings, SSBREM Shariah Supervisory remuneration, control variables consist of bank size, listing, Real Gross Domestic Product per capita and inflation rate.

Measurement of Dependent Variable

This study represents credit risk to explain the dependent variable. Berger and DeYoung (1997) previously used the non-performing loan (NPL) ratio as a proxy for credit risk. In banking studies, a loan is classified as NPL if the interest and principal payments are 90 days or more past due. Higher NPLs result in lower profit margins for banks, and if the problem worsens, it can lead to a crisis.in this study, credit risk is calculated by dividing the NPL and Gross loan of the bank. Specific variable definitions are explained in table 3. 
INTERNATIONAL JOURNAL OF ACADEMIC RESEARCH IN ACCOUNTING, FINANCE AND

MANAGEMENT SCIENCES

Vol. 11, No. 3, 2021, E-ISSN: 2225-8329 ๔ 2021 HRMARS

Table 3: Definition of the Variables

\begin{tabular}{|c|c|c|c|c|}
\hline $\begin{array}{l}\text { TYPES } \\
\text { VARIABLE }\end{array}$ & VARIABLE & $\begin{array}{l}\text { ABBREVIATION } \\
\text { OF VARIABLE }\end{array}$ & MEASUREMENT & SOURCES \\
\hline $\begin{array}{l}\text { DEPENDENT } \\
\text { VARIABLE }\end{array}$ & Credit Risk & RISK & $\begin{array}{l}\text { The Ratio of non- } \\
\text { performing loan to } \\
\text { gross loan. }\end{array}$ & $\begin{array}{l}\text { Bank Scope } \\
\text { and annual } \\
\text { report }\end{array}$ \\
\hline \multirow[t]{5}{*}{$\begin{array}{l}\text { INDEPENDENT } \\
\text { VARIABLES }\end{array}$} & $\begin{array}{l}\text { Shariah } \\
\text { Supervisory } \\
\text { board size }\end{array}$ & SSBS & $\begin{array}{l}\text { The total number } \\
\text { of shariah } \\
\text { supervisor boards } \\
\text { members. }\end{array}$ & $\begin{array}{l}\text { Annual } \\
\text { report and } \\
\text { bank } \\
\text { website }\end{array}$ \\
\hline & $\begin{array}{l}\text { Shariah } \\
\text { Supervisory } \\
\text { board } \\
\text { independent }\end{array}$ & SSBINP & $\begin{array}{l}\text { The proportion of } \\
\text { independent } \\
\text { members to total } \\
\text { SSB size }\end{array}$ & $\begin{array}{l}\text { Annual } \\
\text { report and } \\
\text { bank } \\
\text { website }\end{array}$ \\
\hline & $\begin{array}{l}\text { Shariah } \\
\text { Supervisory } \\
\text { board female }\end{array}$ & SSBFP & $\begin{array}{l}\text { The proportion of } \\
\text { female members } \\
\text { to total SSB size }\end{array}$ & $\begin{array}{l}\text { Annual } \\
\text { report and } \\
\text { bank } \\
\text { website }\end{array}$ \\
\hline & $\begin{array}{l}\text { Shariah } \\
\text { Supervisory } \\
\text { Board } \\
\text { meetings }\end{array}$ & SSBM & $\begin{array}{l}\text { Total numbers of } \\
\text { Shariah } \\
\text { Supervisory } \\
\text { boards meeting in } \\
\text { a year }\end{array}$ & $\begin{array}{l}\text { Annual } \\
\text { report }\end{array}$ \\
\hline & $\begin{array}{l}\text { Shariah } \\
\text { Supervisory } \\
\text { remuneration }\end{array}$ & SSBREM & $\begin{array}{l}\text { Natural logarithm } \\
\text { of board } \\
\text { remuneration }\end{array}$ & $\begin{array}{l}\text { Annual } \\
\text { report }\end{array}$ \\
\hline \multirow[t]{2}{*}{$\begin{array}{l}\text { BANKS SPECIFIC } \\
\text { VARIABLES }\end{array}$} & Bank size & LNSIZE & $\begin{array}{l}\text { Natural logarithm } \\
\text { of total assets }\end{array}$ & $\begin{array}{l}\text { Bankscope } \\
\text { and annual } \\
\text { report }\end{array}$ \\
\hline & Listing & LISTING & $\begin{array}{l}\text { Coded as } 1 \text { if the } \\
\text { bank is listing, } \\
\text { otherwise is } 0\end{array}$ & $\begin{array}{l}\text { Annual } \\
\text { report }\end{array}$ \\
\hline \multirow[t]{2}{*}{$\begin{array}{l}\text { COUNTRY } \\
\text { SPECIFIC } \\
\text { VARIABLES }\end{array}$} & $\begin{array}{l}\text { Real gross } \\
\text { domestic } \\
\text { product per } \\
\text { capita }\end{array}$ & LNGDPC & $\begin{array}{l}\text { Natural logarithm } \\
\text { of real gross } \\
\text { domestic product } \\
\text { per capita }\end{array}$ & $\begin{array}{l}\text { Thomas } \\
\text { Reuters } \\
\text { Datastream }\end{array}$ \\
\hline & Inflation rate & INFL & Inflation rate & $\begin{array}{l}\text { Thomas } \\
\text { Reuters } \\
\text { Datastream }\end{array}$ \\
\hline
\end{tabular}

\section{Results and Discussion}

Table 4 shows descriptive statistics for shariah supervisory boards' features as an independent variable and credit risk as the dependent variable. Since this study used unbalanced panel data, the number of observations varies, as seen in Colum two of table 4. Based on table 4, the mean value for the credit risk is 11 percent, while the minimum is 1 percent and the maximum are 94 percent. Therefore, due to the high amount of credit risk, banks must increase loan loss provisions. The average number of members of the SSB is 4 and 


\section{MANAGEMENT SCIENCES}

Vol. 11 , No. 3, 2021, E-ISSN: 2225-8329 @ 2021 HRMARS

at least the board has 1 independent member. The maximum female proportion of the board is 50 percent and 3 percent on average of the total sample. Table 4 shows, on average, the boards at least meet 4 times a year. Last but not least, only 50 percent of the IBs in this study was listed.

The Pearson correlation matrix for all variables (e.g. dependent variable, independent variable, control variable) is shown in Table 5 . This analysis measures a linear correlation between two sets of data. The result always between -1 and 1 . Correlation matrix reveals one variable with a high degree of intercorrelation (correlation value greater than 0.5 ). Additionally, this test is calculated to detect multicollinearity, which occurs when two or more independent variables exhibit a high degree of interaction. In this study, only control variable for country which is INFL and LNGDPC reported a high correlation (-0.6259). The variance inflation test (VIF) is conducted to a further test of multicollinearity. The result for the VIF is below 10 , suggests that no severe multicollinearity exists from the variable used.

Table 4: Descriptive Statistics of IBs for 2009-2017

\begin{tabular}{lllllllll}
\hline VARIABLES & $\begin{array}{c}\text { OBSERVA } \\
\text { ION }\end{array}$ & MEAN & $\begin{array}{l}\text { MEDIA } \\
\text { N }\end{array}$ & $\begin{array}{c}\text { STD. } \\
\text { DEV. }\end{array}$ & MIN & MAX & \multicolumn{3}{c}{ SKEW. } & \\
\hline RISK & 413 & 0.110 & 0.06 & 0.149 & 0.01 & 0.94 & 2.678 & 10.915 \\
SSBS & 465 & 4.159 & 4.00 & 1.838 & 1.00 & 11.00 & 1.382 & 5.687 \\
SSBINP & 465 & 0.98 & 1.00 & .065 & 0.70 & 1.00 & -3.186 & 11.61 \\
SSBFP & 465 & 0.03 & 0.00 & .096 & 0.00 & 0.50 & 3.259 & 12.502 \\
SSBM & 465 & 7.551 & 6.00 & 7.109 & 0.00 & 47.00 & 3.884 & 19.366 \\
LNSSBREM & 441 & 3.914 & 4.22 & 1.373 & 0.00 & 6.412 & -0.552 & 2.791 \\
LNSIZE & 483 & 14.94 & 15.06 & 1.674 & 9.002 & 18.332 & -0.757 & 4.119 \\
LISTING & 504 & 0.536 & 1.00 & 0.499 & 0.00 & 1.00 & -0.143 & 1.021 \\
LNGDPC & 504 & 9.344 & 9.29 & 1.5 & 6.524 & 11.392 & -0.264 & 1.777 \\
INFL & 504 & 3.671 & 3.19 & 3.784 & - & 29.502 & 1.659 & 11.604 \\
& & & & & 4.863 & & & \\
\hline
\end{tabular}




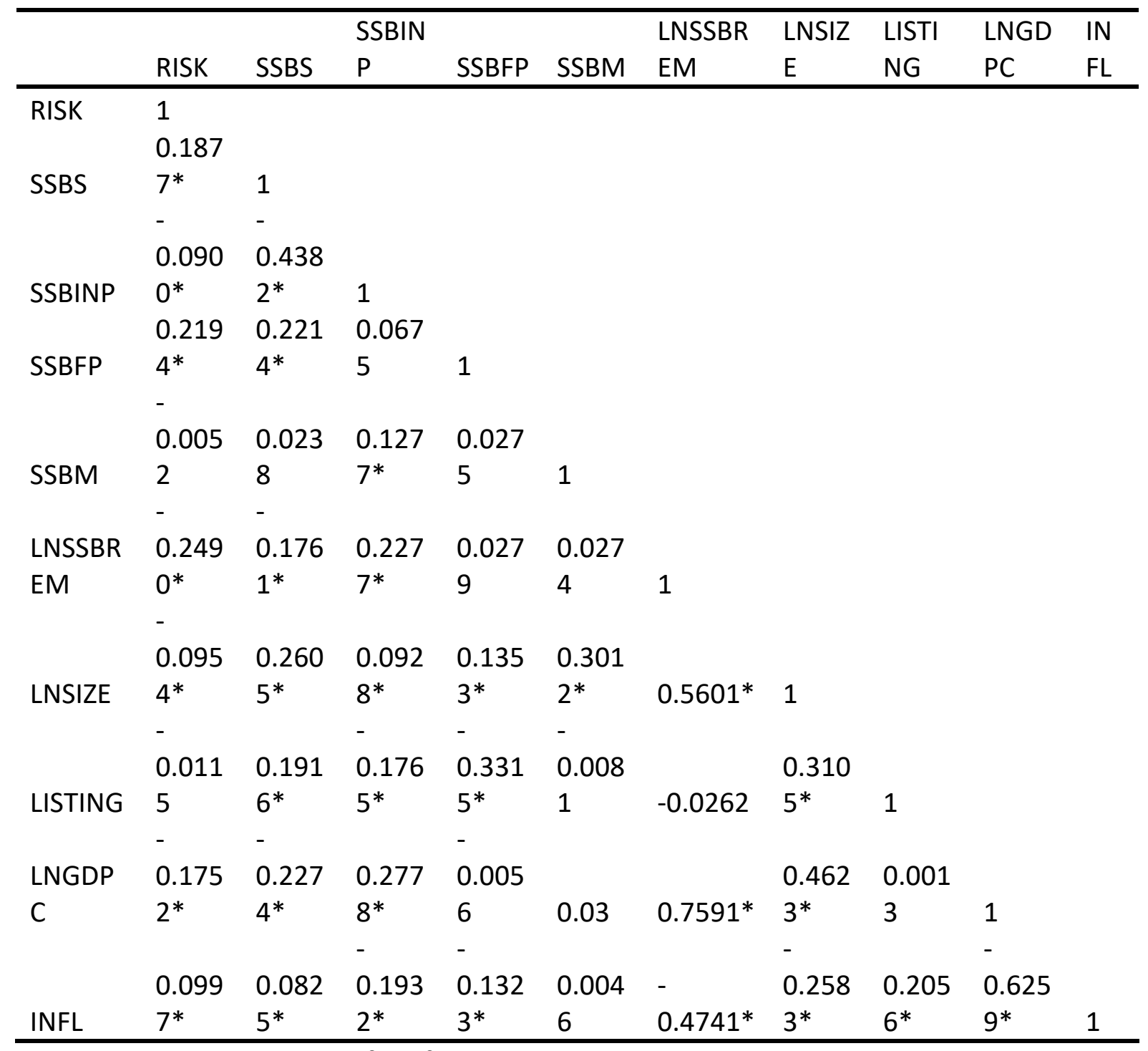

Table 5: Correlation Matrix of IBs for 2009 -2017

Note: This table shows a person correlation matrix. ${ }^{*}$ indicates significant at least at $10 \%$ levels. 
MANAGEMENT SCIENCES

Vol. 11, No. 3, 2021, E-ISSN: 2225-8329 @ 2021 HRMARS

Multivariate Regression Analysis

Table 6: Multivariate Regression Analysis of the Variation in SSB Characteristics and Credit Risk in IBs

\begin{tabular}{|ll|}
\hline & MODEL 1 \\
VARIABLES & RISK \\
\hline SSBS & $0.015^{* * *}$ \\
SSBINP & $(0.005)$ \\
& -0.027 \\
SSBFP & $(0.129)$ \\
& $0.380^{* * *}$ \\
SSBM & $(0.091)$ \\
& 0.002 \\
LNSSBREM & $(0.001)$ \\
& $-0.019 * *$ \\
LNSIZE & $(0.009)$ \\
& $-0.016^{* *}$ \\
LISTING & $(0.007)$ \\
LNGDPC & 0.016 \\
& $(0.017)$ \\
INFL & 0.008 \\
CONSTANT & $(0.008)$ \\
F-STATISTIC & 0.001 \\
PROBABILITY $>$ F & $(0.003)$ \\
OBSERVATIONS & $0.281^{*}$ \\
R-SQUARED & $(0.154)$ \\
\hline
\end{tabular}

Note: this table presents an OLS regression analysis of the variation in SSB Characteristics and credit risk in IBs. Robust t- statistics are reported. Standard errors in parentheses, $* * *, * *, *$ indicates significance at the 1,5,10 percent level.

Table 6 reports the results of OLS regression for model 1, examining the relationship between SSBS, SSBINP, SSFP, SSBM, SSBREM to estimate the effect of SSB characteristics that influence credit risk. As stated in table 6 , the F-statistics for model 1 is significant $(F=7.06, p<0.000)$ indicate that the independent variables' subset explains the variation in credit risk. A positive relationship is found between the SSBS coefficient and credit risk for model 1 , significant at 1 percent level; thus, hypothesis 1 was accepted. Hereafter, the larger the SSB size, the more IB risk-taking happens. This result could be consistent with a frequent finding in the corporate literature that larger boards are less effective than controlling mechanisms (Mollah et al., 2017). In addition, this study found a negative relationship between SSBINP and credit risk, indicating that more independent directors (SSBINP) will reduce the credit risk in IB. However, this finding contradicts (Mollah et al., 2017) who found a positive relationship between the independent board and credit risk. SSBFB has a positive, significant relationship with risk at 1 
MANAGEMENT SCIENCES

Vol. 11, No. 3, 2021, E-ISSN: 2225-8329 @ 2021 HRMARS

percent level. Thus, this result contradicts past research (Faccio et al. 2016; Perryman et al., 2016). This result also explains that female directors' presence does not reduce the risk in IB (khan et al., 2020). As a result, hypothesis 3 was rejected. As shown in table 6, the regression estimation shows a negative and significant relationship between LNSSBREM and credit risk. This indicates that more remuneration has been paid to the board; thus, IBs indicates less risk. According to (Unda et al., 2019), individuals exert tremendous effort when compensated more than less. Thus hypothesis 4 was accepted.

\section{Conclusion}

This study examined the relationship between SSB and credit risk by using a sample of 504 IBS year observations from 56 IBs in 18 countries over the period 2009-2017. Five SSB variables represent SSB characteristics; meanwhile, credit risk is measured by NPL(non-performing loan). The primary analysis of this study uses OLS regression. In terms of the relationship between SSB and credit risk, our results reveal that three variables are positively related to credit risk: SSB size, the proportion of SSB female boards members, and the frequency of SSB meetings. On the other hand, two variables indicate a negative relation with credit risk: the proportion of SSB independent members and the total SSB remuneration. Interestingly, our results show no significant evidence for the proportion of SSB independent members and the frequency of SSB meetings with credit risk. This study concludes that the small size of SSB members, fewer proportion of SSB female members and high remuneration payout to SSB members will reduce credit risk.

The findings are invaluable resources to the IBs, regulators and researchers. Firstly, banks must decide on an appropriate risk level for their operations depending on their risk exposure. This is because different banks have their own preferences on optimum level of the risk. Therefore, if the IBs prefer to lower their credit risk, IBs should reduce the size of SSB members because small SSB size will help the IBs make a decisive decision. Furthermore, increasing the remuneration to the SSB members will also increase of the efforts on decision making by the IBs. Secondly, regulators may focus more on IBs with large SSB members and low remuneration payout to SSB members in order to observe IBs credit risk and address a future financial crisis. Thirdly, this study contributes to the body of knowledge in Shariah governance by examining the characteristics of SSBs. However, this study used a small sample size due to the limitation of the data. Therefore, future research with a large sample size is needed to enhance the influences of the SSB in IBs. The countries represented in this study have made significant contributions to the infrastructures of Islamic financial institutions around the world. Finally, the study outcome might also serve as another model for countries which seek to strengthen the role of SSB in managing IBs credit risk. We recommend that future research will expand on the issues explored in our study by adding different risk measurements to obtain more valuable findings.

\section{References}

Abedifar, P., Molyneux, P., \& Tarazi, A. (2013). Risk in Islamic banking. Review of Finance, 17(6), 2035-2096.

Abozaid, A. (2016). The internal challenges facing Islamic finance industry. International Journal of Islamic and Middle Eastern Finance and Management.

Abu-Tapanjeh, A. M. (2009). Corporate governance from the Islamic perspective: A comparative analysis with OECD principles. Critical Perspectives on accounting, 20(5), 556-567. 
MANAGEMENT SCIENCES

Vol. 11, No. 3, 2021, E-ISSN: 2225-8329 ๔ 2021 HRMARS

Ahmad, N. F. G., Zamil, N. A. M., Basiruddin, R., \& Saruchi, S. A. (2019). The Ownership Structure, Capital and Bank Lending in Times of Crisis: Islamic Banks versus Conventional Banks. International Journal of Academic Research in Accounting, Finance and Management Sciences, 9(3), 150-159.

Ahmed, H., \& Chapra, M. U. (2002). Corporate Governance in Islamic Financial Institution (Occasional Paper) (No. 93). The Islamic Research and Teaching Institute (IRTI).

AlAbbad, A., Hassan, M. K., \& Saba, I. (2019). Can Shariah board characteristics influence risktaking behavior of Islamic banks? International Journal of Islamic and Middle Eastern Finance and Management.

Alam, M. K., Islam, F. T., \& Runy, M. K. (2021). Why does Shariah governance framework important for Islamic banks? Asian Journal of Economics and Banking.

Alman, M. (2012). Shari'ah supervisory board composition effects on Islamic banks' risktaking behavior. Journal of Banking Regulation, 14(1), 134-163.

Ali, M., Khattak, M. A., \& Alam, N. (2021). Credit risk in dual banking systems: does competition matter? Empirical evidence. International Journal of Emerging Markets.

Alzoubi, T., \& Obeidat, M. (2020). How size influences the credit risk in Islamic banks. Cogent Business \& Management, 7(1), 1811596.

Barber, B. M., \& Odean, T. (2001). Boys will be boys: Gender, overconfidence, and common stock investment. The quarterly journal of economics, 116(1), 261-292.

Becht, M., Bolton, P., \& Röell, A. (2011). Why bank governance is different. Oxford review of economic policy, 27(3), 437-463.

Bourakba, C., \& Zerargui, H. (2015). The relationship between credit risk and corporate governance in Islamic banking: An empirical study. Issues in business management and economics, 3(4), 67-73.

Chaganti, R. S., Mahajan, V., \& Sharma, S. (1985). Corporate board size, composition and corporate failures in retailing industry [1]. Journal of management studies, 22(4), 400417.

Charness, G., \& Gneezy, U. (2012). Strong evidence for gender differences in risk taking. Journal of Economic Behavior \& Organization, 83(1), 50-58.

Chen, C. J., \& Jaggi, B. (2000). Association between independent non-executive directors, family control and financial disclosures in Hong Kong. Journal of Accounting and Public policy, 19(4-5), 285-310.

Cheng, S. (2008). Board size and the variability of corporate performance. Journal of financial economics, 87(1), 157-176.

Chowdhury, N., \& Shaker, F. (2015). Shariah governance framework of the islamic banks in Malaysia. International Journal of Management Sciences and Business Research, 4(10).

Croson, R., \& Gneezy, U. (2009). Gender differences in preferences. Journal of Economic literature, 47(2), 448-74.

El-Hawary, D., Grais, W., \& Iqbal, Z. (2007). Diversity in the regulation of Islamic financial institutions. The Quarterly Review of Economics and Finance, 46(5), 778-800.

Faccio, M., Marchica, M. T., \& Mura, R. (2016). CEO gender, corporate risk-taking, and the efficiency of capital allocation. Journal of corporate finance, 39, 193-209.

Fama, E. F., \& Jensen, M. C. (1983). Separation of ownership and control. The journal of law and Economics, 26(2), 301-325.

Halko, M. L., Kaustia, M., \& Alanko, E. (2012). The gender effect in risky asset holdings. Journal of Economic Behavior \& Organization, 83(1), 66-81. 
MANAGEMENT SCIENCES

Vol. 11, No. 3, 2021, E-ISSN: 2225-8329 @ 2021 HRMARS

Hamza, H., \& Saadaoui, Z. (2013). Investment deposits, risk-taking and capital decisions in Islamic banks. Studies in Economics and Finance.

Hasan, Z. B. (2009). Regulatory framework of Shari'ah governance system in Malaysia, GCC Countries and the UK. Kyoto Bulletin of Islamic Area Studies, 3-2.

IFSB, I. (2014). Revised Guidance on Key Elements in the Supervisory Review Process. Islamic Financial Services Board. Kuala Lumpur. 1-58

Jensen, M. C., \& Meckling, W. H. (1976). Theory of the firm: Managerial behavior, agency costs and ownership structure. Journal of financial economics, 3(4), 305-360.

John, K., \& Qian, Y. (2003). Incentive features in CEO compensation in the banking industry. Economic Policy Review, 9(1).

Khan, M. H., Fraz, A., Hassan, A., \& Abedifar, P. (2020). Female board representation, risktaking and performance: Evidence from dual banking systems. Finance Research Letters, 37, 101541.

Khan, T., \& Ahmed, H. (2001). Risk management: an analysis of issues in Islamic financial industry (occasional papers) (No. 91). The Islamic Research and Teaching Institute (IRTI).

Laeven, L., \& Levine, R. (2009). Bank governance, regulation and risk taking. Journal of financial economics, 93(2), 259-275.

Miller, L., \& Ubeda, P. (2012). Are women more sensitive to the decision-making context? Journal of Economic Behavior \& Organization, 83(1), 98-104.

Mollah, S., \& Zaman, M. (2015). Shari'ah supervision, corporate governance and performance: Conventional vs. Islamic banks. Journal of Banking \& Finance, 58, 418435.

Mollah, S., Skully, M. T., \& Liljeblom, E. (2017). Strong Board and Risk-Taking in Islamic Banks. Available at SSRN 2905179.

Muneeza, A., \& Hassan, R. (2014). Shari'ah corporate governance: the need for a special governance code. Corporate Governance.

Najwa, N. A., Ramly, Z., \& Haron, R. (2020). Board size, chief risk officer and risk-taking in Islamic banks: role of Shariah supervisory board. Jurnal Pengurusan (UKM Journal of Management), 57.

Pathan, S. (2009). Strong boards, CEO power and bank risk-taking. Journal of banking \& finance, 33(7), 1340-1350.

Perryman, A. A., Fernando, G. D., Tripathy, A. (2016). Do gender differences persist? An examination of gender diversity on firm performance, risk, and executive compensation. J. Bus. Res. 69 (2), 579-586.

Rachdi, H., Trabelsi, M. A., \& Trad, N. (2013). Banking governance and risk: The case of Tunisian conventional banks.

Ramly, Z., \& Nordin, N. D. H. M. (2018). Sharia Supervision Board, Board Independence, Risk Committee and Risk-taking of Islamic Banks in Malaysia. International Journal of Economics and Financial Issues, 8(4), 290-300.

Tung, F., \& Wang, X. (2012). Bank CEOs, inside debt compensation, and the global financial crisis. Boston Univ. School of Law Working Paper, (11-49).

Ulfi, I., Mubarrok, U. S., \& Wahyudi, M. (2020). Optimization the Role of Shariah Supervisory Board for Shariah Governance in Islamic Banking. Perisai: Islamic Banking and Finance Journal, 4(1), 47-47.

Unda, L. A., \& Ranasinghe, D. (2019). To pay or not pay: Board remuneration and insolvency risk in credit unions. Pacific-Basin Finance Journal, 101128. 
Usmani, T. (2008). Islamic finance: musharakah \& mudarbah. Journal of Islamic Banking and Finance, 25(3), 41-53.

Vafeas, N. (1999). Board meeting frequency and firm performance. Journal of financial economics, 53(1), 113-142.

Waemustafa, W., \& Sukri, S. (2015). Bank specific and macroeconomics dynamic determinants of credit risk in Islamic banks and conventional banks. International Journal of Economics and Financial Issues, 5(2), 476-481.

Zabri, S. M., Ahmad, K., \& Wah, K. K. (2016). Corporate governance practices and firm performance: Evidence from top 100 public listed companies in Malaysia. Procedia Economics and Finance, 35, 287-296.

Zalewska, A. (2016). A new look at regulating bankers' remuneration. Corporate Governance: An International Review, 24(3), 322-333. 